\title{
CLIMATIC CHANGE DETECTION IN THE NORTHWESTERN COASTAL ZONE (EGYPT) AND ITS POSSIBLE IMPACT ON WATER RESOURCE
}

\author{
Abdel Moghith, Salah M. ${ }^{1}$, Nahla A. Morad ${ }^{1 *}$ and Milad H. \\ Masoud $^{2}$ \\ ${ }^{1}$ Department of Hydrology, Desert Research Center, Egypt \\ ${ }^{2}$ Water Research Center, King Abdulaziz University, Saudi Arabia \\ *E-mail: nahlamorad@hotmail.com
}

T $\mathrm{n}$ the study area, which extends for about $500 \mathrm{~km}$ along the Mediterranean coast of Egypt, the seasonal rainfall is the sole source of water for development activities through either runoff harvesting or shallow aquifer recharge. Rainfall and other meteorological data in the study area were collected from two sources: NASA satellite site and ground stations; namely from west to east Sallum, Barrani, Matruh, Dabaa and Alexandria. Such data have been analyzed to detect and assess any spatial and temporal climatic changes during the period (1900-2014) and the possible impacts upon the shallow groundwater potentials.

During the last century, the highest value of annual rainfall was recorded in Alexandria in $1974(405.1 \mathrm{~mm})$, while the lowest value was recorded in Sallum in 1955 (32.8 mm). This may indicate that extreme climatic conditions were prevailing during the period (1955-1970) from further west to further east. The calculated arithmetic mean of the annual rainfall in the study area is 138.44 $\mathrm{mm}$. The rainfall frequency during the whole period of measurements shows continuous fluctuation either below (Sallum), or above (Alexandria) arithmetic mean. Local climatic changes every 15 years or multiples in the study area are detected through the period 1900-2014. Variations during the whole period of records are well detected, where it ranged from $76.5 \mathrm{~mm}$ (Matruh, 1923), 76 $\mathrm{mm}$ (Barrani, 1913) and $62 \mathrm{~mm}$ (Alexandria, 1938) indicating relative wet condition in the first third of the past century (19101940), compared with the whole period. The return period shows that the probability for the occurrence of annual rainfall can be doubled from the mean every about sixty years in all stations except for Sallum, where it be doubled every only 30 years. According to the calculated aridity index, the study area lies between hyper arid in the west to arid climate in the east, without any serious spatial or temporal changes. The temperature analysis indicates that there is a noticeable increase in temperature between the years 1955-1970 and 
1995-2010. Worth mentioning the year 2010 is one of the warmest years during this period. In addition, this year (2010) had the lowest amount of rainfall in all the study area (average $50 \mathrm{~mm} / \mathrm{year}$ ). Consequently, the study area was subject to two drought periods (1955-1970 and 1995-2010) against one relative wet period (19101940). The shallow groundwater has been considerably influenced by climatic change in the study area. Water levels have been prominently decreased to about $16.0 \mathrm{~m}$ below the mean sea level (zero level) in some localities; e.g. Dabaa - east Matruh. Meanwhile, water salinity increased from about $3000 \mathrm{ppm}$ (1970) to more than $10000 \mathrm{ppm}$ (2010). The water shortage in the drought events, as well as, the over-pumping of wells, cause serious reduction of the thickness of the fresh water lens that floats by specific gravity on the top of the saline water.

Keywords: climate change, water resources, rainfall analysis, return period, Northwest coast, Egypt

The climatic change is defined as the deviation of the climate elements from the normal rates as a result of the action of any of the processes affecting the climatic system (NOAA National Weather Service, 2007). The aim of this work is to detect and analyze the climatic changes, during 114 years (1900-2014), along the Northwestern coast of Egypt, as one of the most important rain-fed agricultural zones in the country. The possible impact of such change on the occurrence and quality of groundwater resources is monitored and assessed.

Detailed rainfall data were collected and analyzed for the period 1900-2014, in decadal classification, from the Egyptian Meteorological Authority (EMA, 1900-1994) and from NASA web site for Rainfall Data (1995-2014). On the other hand, full meteorological data were collected from five stations distributed along the coast namely from west to east: Sallum, Barrani, Matruh, Dabaa and Alexandria. Meanwhile, the present work is deeply concerned with the comparison of changes in groundwater potentials between the present status and that was dominated in the sixties and seventies of the last century. Bearing in mind that groundwater in this area is solely recharged by direct rainfall and naturally affected by drought events. The investigated water points (100 wells) were monitored, sampled and chemically analyzed to evaluate the impact of any water shortage along the whole area and during the whole period.

The study area $\left(29000 \mathrm{~km}^{2}\right)$ extends from near Alexandria in the east to Sallum in the west (500 km distance). It is bound by the Mediterranean Sea in the north and by the elevated limestone plateau $(+200 \mathrm{~m})$ at south (Fig.1). 


\section{MATERIALS AND METHODS}

\section{Physiography and Geology}

The ground surface in the study area slopes towards the north, from about $200 \mathrm{~m}$ above mean sea level to the zero level at the Mediterranean shoreline.

According to Conoco (1989) and Saleh (2000), the study area is divided into the following main physiographic units from north to south (Fig. 2);

\subsection{The coastal plain}

The width of the coastal plain is ranging between 10 to $35 \mathrm{~km}$. The coastal plain stretches in east-west direction, bounded by the sea to the north and a piedmont plain to the south. This area is covered by sediments belonging to the Quaternary age, including a number of ridges and depressions parallel to the shoreline, formed from porous Oolitic Limestone, attaining increased elevations towards the south from +15 to $+50 \mathrm{~m}$ above mean sea level.

\subsection{The piedmont slopes}

The piedmont slope in the area of study is considered as a transitional zone between the foot of the escarpment at south and the coastal plain at north. Its elevation ranges from +50 to $+100 \mathrm{~m}$ toward the south. The piedmont slope is considered as a good water collector that can be infiltrated to the shallow aquifers.

\subsection{The southern plateau}

It occupies the northern edge of the high structural plateau (Marmarica Plateau) of the Western Desert of Egypt. Such Plateau mainly consists of Middle Miocene fissured carbonate rocks, attaining a maximum altitude of $200 \mathrm{~m}$ above mean sea level. Many wadis are dissecting this plateau, running from south to north.

\subsection{The hydrographic basins}

A number of 218 hydrographic basins are found mainly in the western sector of the study area, from Dabaa to Sallum. Such basins are of gentle slope towards the coastal plain, having different catchment areas and acting as favorable water collectors during the rainy periods (Table 1). 


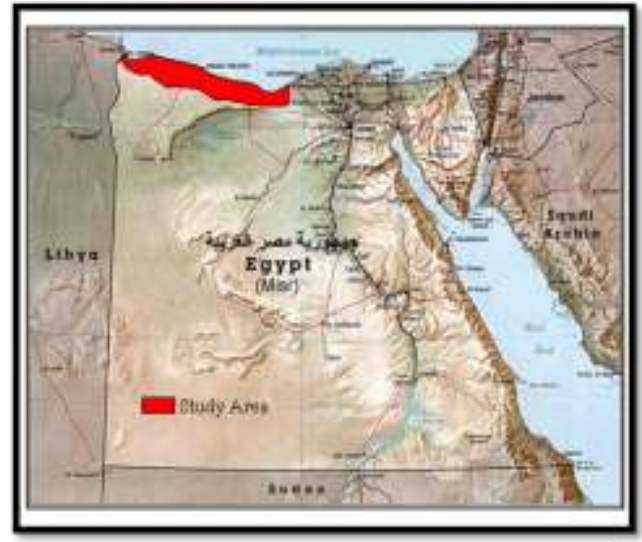

Fig. (1). Location map of the study area (Web Site: Physical Map of Egypt, 2014).

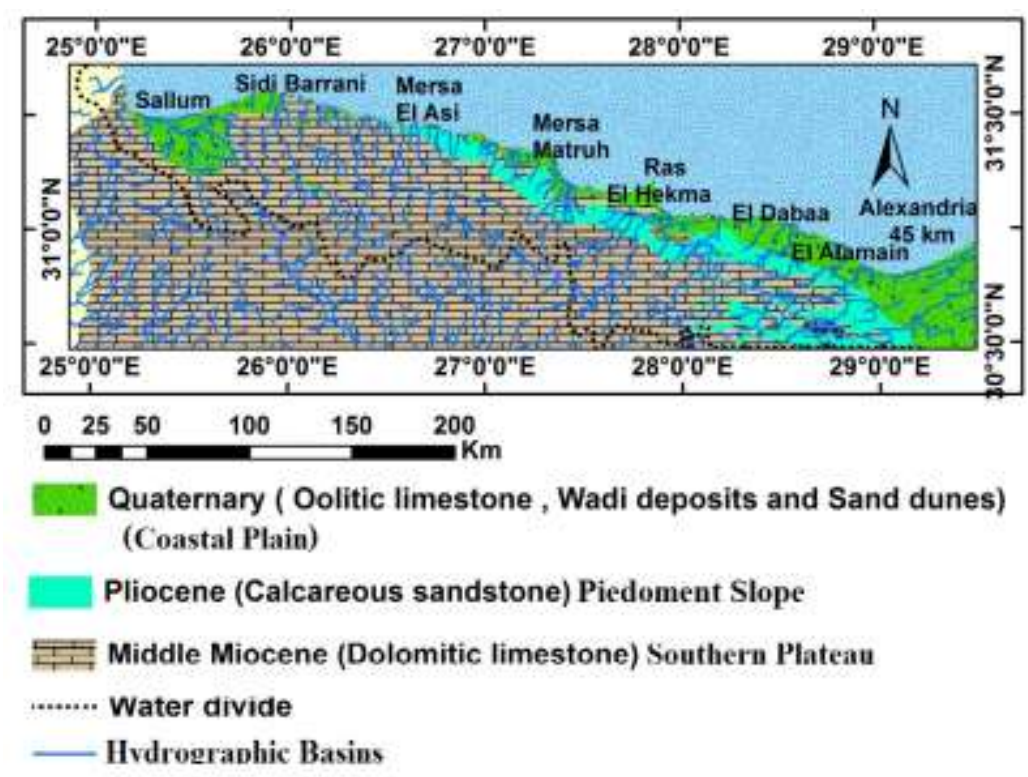

Fig. (2). Physiography and geology of the study area.

Egyptian J. Desert Res., 65, No. 2, 233-255 (2015) 
Table (1). Physiographic characteristics of wadis dissecting the Southern plateau (FAO, 1970).

\begin{tabular}{|c|c|c|c|c|c|c|}
\hline \multirow{2}{*}{ Sector } & \multirow{2}{*}{$\begin{array}{c}\text { Extent } \\
(\mathbf{k m})\end{array}$} & \multirow{2}{*}{$\begin{array}{l}\text { No. of } \\
\text { wadis }\end{array}$} & \multicolumn{2}{|c|}{ Area of wadis $\left(\mathrm{km}^{2}\right)$} & \multirow{2}{*}{$\begin{array}{c}\text { Total area } \\
\left(\mathbf{k m}^{2}\right)\end{array}$} & \multirow{2}{*}{$\begin{array}{c}\text { Mean } \\
\text { slope }\end{array}$} \\
\hline & & & From & To & & \\
\hline Dabaa-Matruh & 125 & 47 & 0.97 & 148.67 & 1812.35 & 0.0074 \\
\hline Matruh-Barrani & 150 & 89 & 0.62 & 76.89 & 1505.74 & 0.00503 \\
\hline Barrani-Sallum & 80 & 83 & 0.62 & 124.35 & 1409.42 & 0.0188 \\
\hline
\end{tabular}

\section{Regional Climatic Characteristics}

Table (2) shows the average monthly climatic parameters in the study area (EMA, 1900-1994) and NASA web site (1995-2014), from which the following can be noticed: -

- The rainy season is mainly from October to February (autumn \& winter seasons). Generally, the rainfall increases towards the Eastern direction.

- The maximum value of monthly rainfall is recorded in January in all the stations

- The average monthly evaporation per day ranges between 3.31 $\mathrm{mm} /$ day in December (Alexandria location) and $8.55 \mathrm{~mm} /$ day in June (Sallum location).

- The winds in Matruh and Barrani blow strongly during winter and early spring seasons $(24.9 \mathrm{~km} / \mathrm{hr})$ causing more rainfall intensity. In Dabaa and Sallum location, it is 25\% less than Matruh and Barrani (FAO, 1970).

- From the data of average annual rainfall, a contour map is plotted (Fig. 3) (Zaki, 2000), where the following can be noticed:-

i. There is a gradual increase in the average annual rainfall from west (104.6 $\mathrm{mm}$ at Sallum location) to east (181 $\mathrm{mm}$ at Alexandria location); i.e. at an increasing rate of $2 \mathrm{~mm} / 10 \mathrm{~km}$ (Fig. 4).

ii. The zero contour line of the average annual rainfall lies at a maximum distance of about $100 \mathrm{~km}$ south of the shoreline at an elevation of about $200 \mathrm{~m}$ (above mean sea level).

iii. There is a gradual increase in the average annual rainfall from south to north (shoreline), at a rate of nearly $2 \mathrm{~mm} / 10 \mathrm{~km}$, i.e. the same as in the east-west direction but at a shorter distance $(60 \mathrm{~km})$ leading to considerable surface runoff.

iv. In the area of Barrani, the average annual rainfall (contour line 100 $\mathrm{mm}$ ) lies at a quite short distance from the shoreline (less than 20 $\mathrm{km}$ ), which means that Barrani area is susceptible to receive 
intensive rainfall and runoff compared with the other parts of the study area.

v. Barrani - Matruh sector (140 km length), the rainfall water divide (200 $\mathrm{m}$ above mean sea level) lies at a very short distance $(30 \mathrm{~km})$ south of the shoreline leading to hazardous runoff at heavy storm.

Table (2). Average monthly climatic data (1900-2014) (EMA, 1900-1994) and NASA web site (1995-2014).

\begin{tabular}{|c|c|c|c|c|c|c|c|c|c|c|c|c|c|c|c|c|}
\hline \multicolumn{4}{|c|}{ Station } & \multirow[b]{2}{*}{ Parameter } & \multirow[b]{2}{*}{ Jan. } & \multirow[b]{2}{*}{ Feb. } & \multirow[b]{2}{*}{ Mar } & \multirow[b]{2}{*}{ Apr } & \multirow[b]{2}{*}{ May } & \multirow[b]{2}{*}{ June } & \multirow[b]{2}{*}{ July } & \multirow[b]{2}{*}{ Ang } & \multirow[b]{2}{*}{ Sep. } & \multirow[b]{2}{*}{ Oct. } & \multirow[b]{2}{*}{ Nor } & \multirow[b]{2}{*}{ Dec. } \\
\hline & Lat. & Long. & $\begin{array}{c}\text { Elevation } \\
\text { (m) } \\
\text { (a.m.s.l.) }\end{array}$ & & & & & & & & & & & & & \\
\hline \multirow{6}{*}{3} & \multirow{6}{*}{$\frac{6}{8}$} & \multirow{6}{*}{$\frac{\dot{a}}{\vec{b}}$} & \multirow{6}{*}{+4.0} & Monthly Rainfall (mm) & 21.8 & 16.2 & 8.8 & 3.6 & 2.5 & 0.4 & 0.0 & 0.2 & 1.4 & 10.2 & 19.0 & 20.7 \\
\hline & & & & $\operatorname{Iar} \operatorname{Tem}(C)$ & 19.2 & 20.1 & 21.7 & 24.6 & 26.6 & 29.8 & 31.0 & 31.0 & 29.3 & 28.1 & 24.1 & 19.7 \\
\hline & & & & Sin Teap (C) & 9.45 & 9.98 & 11.5 & 13.6 & 16.4 & 19.6 & 21.3 & 21.5 & 20.0 & 18.1 & 14.8 & 10.5 \\
\hline & & & & Erapontion (moday) & 6.65 & 6.50 & 690 & 7,75 & 7.20 & 8.56 & 8.25 & $8 . M$ & 7.25 & 7,30 & 6.45 & 6.40 \\
\hline & & & & Wiad Speed (km hr) & 159 & 14.5 & 14.8 & 13.5 & 11.9 & 13.7 & 15.4 & 14.1 & 12.0 & 119 & 12.8 & 16.5 \\
\hline & & & & Retative Hunidity (9) & 75.2 & 62.6 & 67.2 & 59.1 & 59.4 & 61.8 & 64.6 & 66.4 & 699 & 69.0 & 73.4 & 74.5 \\
\hline \multirow{6}{*}{3} & \multirow{6}{*}{$\frac{\dot{m}}{8}$} & \multirow{6}{*}{ 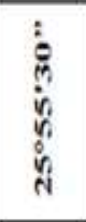 } & \multirow{6}{*}{+21.0} & Ilontly Rainfall (nam) & 36.4 & 25.2 & 13.0 & 1.2 & 2.1 & 0.1 & 0.0 & 0.0 & 1.2 & 169 & 20.0 & 3.1 \\
\hline & & & & Jinx Teng (C) & 17.3 & 17.5 & 19.8 & 21.8 & 239 & 26.6 & 27.8 & 28.9 & 28.4 & 263 & 23.8 & 19.4 \\
\hline & & & & Iin Teap. (C) & 8.90 & 8.90 & 10.8 & 13.0 & 15.6 & 18.8 & 21.6 & 22.3 & 20.4 & 17.6 & 14.5 & 9.8 \\
\hline & & & & Erapontion (mmiday) & 6.75 & 7.17 & 7.77 & 8.07 & 6.43 & 6.53 & 6.43 & 6.5 & 6.94 & 6.98 & 7.16 & 7.04 \\
\hline & & & & Wiad Speed (km hri) & 20.4 & 20.2 & 21.5 & 20.6 & 18.2 & 17.0 & 200 & 17.2 & 15.7 & 15.7 & 16.5 & 19.8 \\
\hline & & & & Relabire Honidity (0) & 67.3 & 59.6 & 66.1 & 62.9 & 65.3 & 72.5 & 73.6 & 74.5 & 73.0 & 72.7 & 71.4 & 73.7 \\
\hline \multirow{6}{*}{$\frac{3}{3}$} & \multirow{6}{*}{ 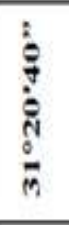 } & \multirow{6}{*}{$\begin{array}{l}0 \\
\vdots \\
i \\
0 \\
0 \\
0\end{array}$} & & Ionthly Roinfall (nm) & 37.6 & 21.4 & 119 & 3.2 & 22 & 0.8 & 0.0 & 0.2 & 09 & 15.8 & 22.4 & 31.6 \\
\hline & & & & $\operatorname{Ser} \operatorname{Ten}\left({ }^{\circ} C\right)$ & 17.6 & 18.3 & 20.0 & 22.6 & 24.7 & 27,4 & 28.5 & 29.1 & 28.4 & 27.2 & 23.5 & 18.7 \\
\hline & & & +50 & Ifin Temp. (C) & 8.8 & 9.01 & 10.5 & 13.0 & 15.2 & 18.7 & 209 & 21.7 & 20.3 & 17.8 & 14.4 & 9.67 \\
\hline & & & The, 0 & Erapontion (mming) & 6.29 & 6.64 & 7.02 & 7.38 & 7.02 & 7.07 & 6.93 & 6.62 & 7.06 & 6.39 & 5.79 & 5.29 \\
\hline & & & & Misd Sped (kmar) & 249 & 233 & 22.8 & 22.6 & 20.0 & 19.3 & 21.4 & 18.7 & 17.8 & 163 & 17.4 & 22.0 \\
\hline & & & & Relabre Homidity (96) & 76.0 & 69.2 & 70.5 & 64.6 & 73.4 & 90.9 & 78.4 & 72.1 & 73.9 & 68.1 & 73.4 & 77.6 \\
\hline & & & & Ilastbly Ruinfall (nmi) & 33.6 & 20.9 & 10.4 & 29 & 15 & 0.1 & 0.0 & 0.1 & 1.2 & 7.8 & 20.5 & 30.6 \\
\hline & $M$ & $g$ & & $\operatorname{Jex} \operatorname{Ten}\left({ }^{\circ} \mathrm{C}\right)$ & 18.2 & 18.3 & 20.6 & 23.2 & 25.5 & 28.5 & 25.0 & 30.4 & 29.3 & 27.2 & 24.1 & 19.8 \\
\hline 3 & $=$ & is & +30 & Ifin Temp. (C) & 8.16 & 8.10 & 9.80 & 12.2 & 14.9 & 18.3 & 20.1 & 21.2 & 20.0 & 17.4 & 14.2 & 9.20 \\
\hline 7 & $\overline{8}$ & s & 490 & Erapontion (miday) & 5.52 & 6.08 & 6.01 & 7.27 & 6.61 & $7.4 !$ & 7.84 & 7.07 & 7.03 & 6.27 & 5.71 & 5.40 \\
\hline & $=$ & 0 & & Wisd Sped (km hri) & 13.1 & 14.1 & 159 & 16.3 & 15.8 & 16.3 & 18.0 & 16.5 & 13.5 & 12.8 & 11.5 & 14.5 \\
\hline & & & & Relabre Humidity (90) & 69.4 & 60.8 & 67.8 & 61.7 & 67.8 & 69.5 & 69.5 & 69.1 & 71.6 & 66.6 & 69.2 & 719 \\
\hline & & & & Ilanthly Ruinfall (mm) & 48.5 & 259 & 13.0 & 4.4 & 1.8 & 0.0 & 0.0 & 0.2 & 0.8 & 8.3 & 31.7 & 5.8 \\
\hline$\frac{\pi}{5}$ & in & 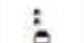 & & $\operatorname{Sex} \operatorname{Ten}(C)$ & 189 & 19.6 & 21.8 & 24.4 & 20.4 & 28.8 & 29.8 & 31.1 & 30.1 & 289 & 25.1 & 20.1 \\
\hline$\underline{z}$ & 7 & กิ & & Inn Teap. (C) & 9.89 & 10.2 & 12.3 & 11.6 & 17.1 & 20.7 & 23.1 & 23.7 & 22.1 & 19.3 & 15.7 & II.2 \\
\hline 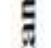 & i & 8 & +8.0 & Erapontion (emiday) & 3.93 & 4.59 & 497 & 5.02 & $49 !$ & 496 & 4.87 & 4.4 & 49 & 4.86 & 3.99 & $3,3 !$ \\
\hline ह & $\stackrel{-}{-}$ & 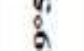 & & Nind Speed (km hr) & 17.0 & 17.2 & 18.2 & 16.7 & 15.4 & 16.5 & 159 & 15.7 & 14.4 & 12.6 & 13.0 & 159 \\
\hline 7 & " & & & Relatire Homidiț (\$0) & 72.1 & 66.4 & 71.3 & 67.6 & 69.1 & 71.1 & cos. & 72.6 & 78.3 & 20.1 & 22.0 & 72.0 \\
\hline
\end{tabular}

Egyptian J. Desert Res., 65, No. 2, 233-255 (2015) 


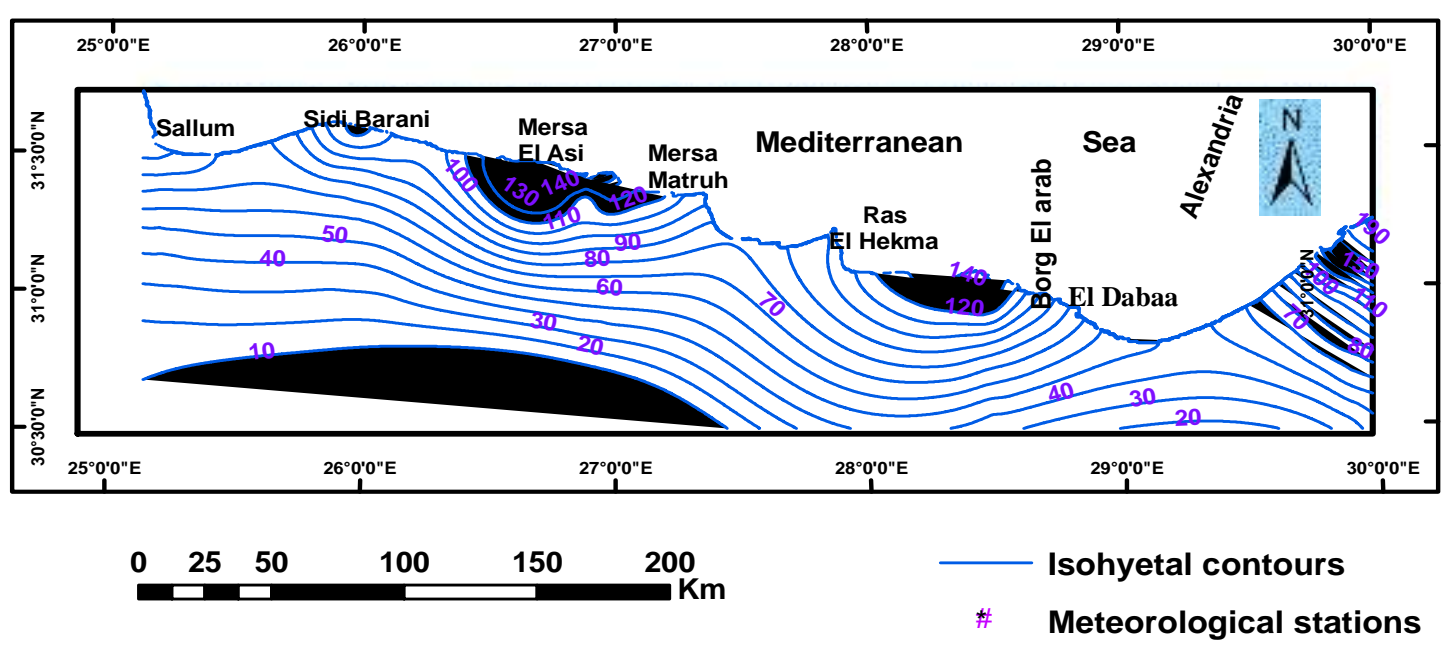

Fig. (3). Isohyetal contour map for the average annual rainfall of the study area (Zaki, 2000).

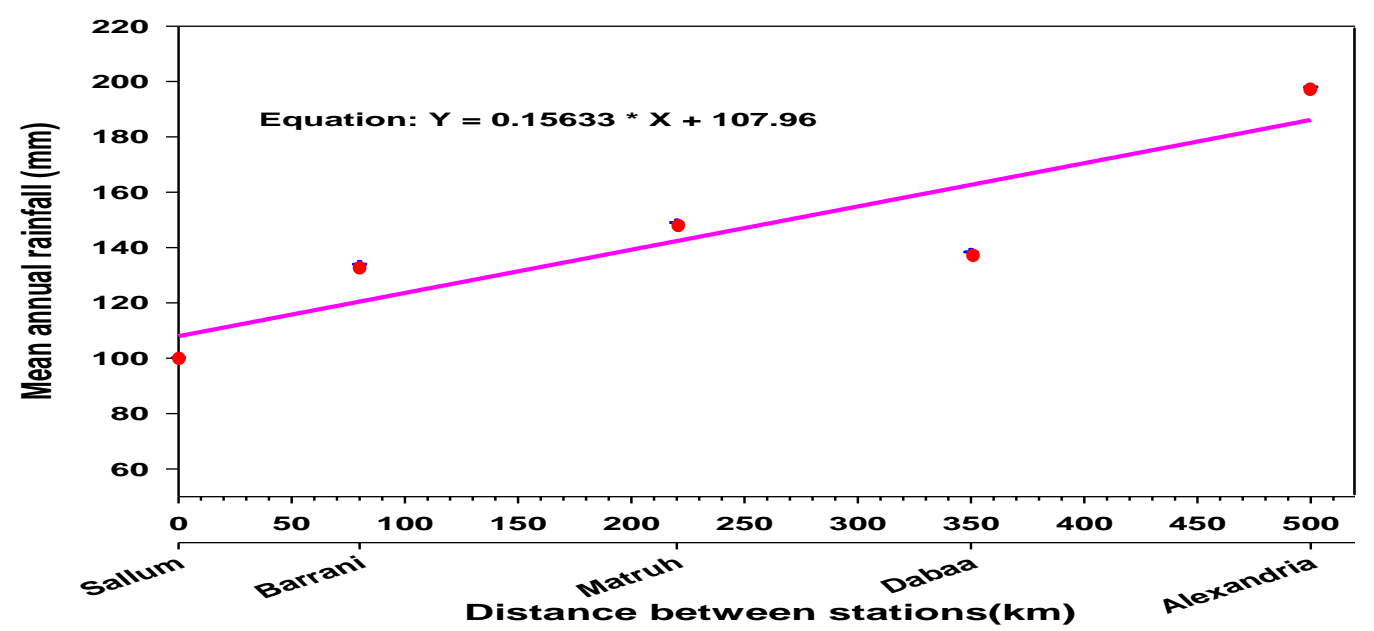

Fig. (4). East-west variation of the mean annual rainfall (1900-2014).

Egyptian J. Desert Res., 65, No. 2, 233-255 (2015) 


\section{RESULTS AND DISCUSSION}

\section{Rainfall Analysis}

The rainfall data used in the following analysis are collected partly from the meteorological ground stations (EMA, 1900-1994) and from NASA satellite site (1995-2014).

\subsection{Rainfall intensity}

A descriptive statistical analysis for the annual rainfall data is tabulated (Table 3).

Table (3). Descriptive statistical analysis for the annual rainfall data (1900-

\begin{tabular}{cccccccc}
\hline Location & Year & $\begin{array}{c}\text { Maximum } \\
\text { rainfall } \\
(\mathbf{m m})\end{array}$ & Year & $\begin{array}{c}\text { Minimum } \\
\text { rainfall } \\
(\mathbf{m m})\end{array}$ & $\begin{array}{c}\text { Mean } \\
(\mathbf{m m})\end{array}$ & $\begin{array}{c}\text { Standard } \\
\text { deviation }\end{array}$ & $\begin{array}{c}\text { Coefficient of } \\
\text { variation }(\mathbf{C V}) \\
(\mathbf{\%})\end{array}$ \\
\hline Alexandria & 1974 & 405.1 & 1931 & 33.2 & 180.8 & 64.0 & $35.40 \%$ \\
Dabaa & 1989 & 288.9 & 1999 & 40.0 & 122.6 & 52.2 & $42.58 \%$ \\
Matruh & 1930 & 384.8 & 1999 & 34.3 & 143.2 & 64.4 & $44.97 \%$ \\
Barrani & 1911 & 375.7 & 2010 & 29.0 & 141.0 & 65.8 & $46.67 \%$ \\
Sallum & 1953 & 324.0 & 1955 & 32.8 & 104.6 & 53.2 & $50.86 \%$ \\
\hline \multicolumn{7}{c}{ Arithmetic Mean } \\
\hline \multicolumn{7}{c}{}
\end{tabular}

The following are noticed:

- Alexandria and Sallum locations are characterized by extreme values of annual rainfall during the whole period due to physiographic features prevail, where Sallum lies in a small bay while Alexandria is a highland.

- The highest values of the annual rainfall range from $405.1 \mathrm{~mm}$ (Alexandria, 1974) and $288.9 \mathrm{~mm}$ (Dabaa, 1989). The lowest values were recorded in Barrani in $2010(29.0 \mathrm{~mm})$ and Dabaa in 1999 (40.0 mm).

- The Standard Deviation shows how much variation or dispersion exists from the average value (mean). A low standard deviation indicates that the data points tend to be very close to the mean; high standard deviation indicates that the data points are spread out over a large range of values. The standard deviation in the study area ranges between 52 and 66 .

- The coefficient of Variation (CV) is defined as the ratio of the standard deviation to the mean. It is a useful statistical tool for comparing the degree of variation from one data series to another (Reed et al., 2002). The coefficient of Variation in the study area ranges from $35 \%$ (Alexandria) to 50\% (Sallum). This means that there is a kind of irregularity for the collected data. 


\subsection{The arithmetic mean and rainfall behavior}

The arithmetic mean of annual rainfall for the whole study area is calculated from the means of all the locations as follows:

$$
\begin{aligned}
& \text { Arithmetic Mean for the study area }(\mathrm{AM})=\frac{\sum_{n=1}^{5} M}{n} \ldots \ldots \ldots \ldots \text { (1) } \\
& =(180.8+122.6+143.2+141.0+104.6) / 5 \\
& =138.44 \mathrm{~mm}
\end{aligned}
$$

The arithmetic mean; the average value of the annual rainfall for the study area is equal to $138.44 \mathrm{~mm}$. Graphs for every location showing the annual rainfall behavior for each 10 years and the corresponding local mean and arithmetic mean are plotted (Fig. 5). From these graphs, the rainfall behavior in the study area during the period 1900-2014 is different from area to area and from time to time, indicating local variations influencing the impact of climatic change in the study area, as follows:

- At Sallum area (extreme west), the rainfall is slightly fluctuating below the arithmetic mean without any prominent abnormalities in almost all the time.

- At Alexandria (extreme east) the condition is quite different, since the rainfall is always above the arithmetic mean with slight fluctuation but at the same position.

- At Matruh and Dabaa, the rainfall is more or less regular and fluctuates very close to the arithmetic mean without any conspicuous peaks.

- At Barrani, the condition is quite different where the rainfall shows sharp peaks and trough all the century round. This may indicate a kind of cyclic change of climate every about 30 years. In addition, such condition indicates that Barrani area is a promising condition for runoff water harvesting and groundwater recharge as well. Bearing in mind that most of the hydrographic basins dissecting the plateaus lie within this particular area (89 wadis).

- Two cycles of peak rainfall can be distinguished in the whole area. One major cycle occurs every 30 years and the other one is minor cycle happens every 15 years. This phenomenon is obvious in all locations except Sallum. The major cycle (30 years) is very clear between the years 1964 and 1994. 
- A relatively wet period was prominently shown during the years 1910-1940, while a dry period during 1995-2010 was strongly indicated in the study area.

- The year 2010 represents one of the driest years in the study period, where the annual rainfall in this year is less than $50 \%$ from the man value in all locations in the study area
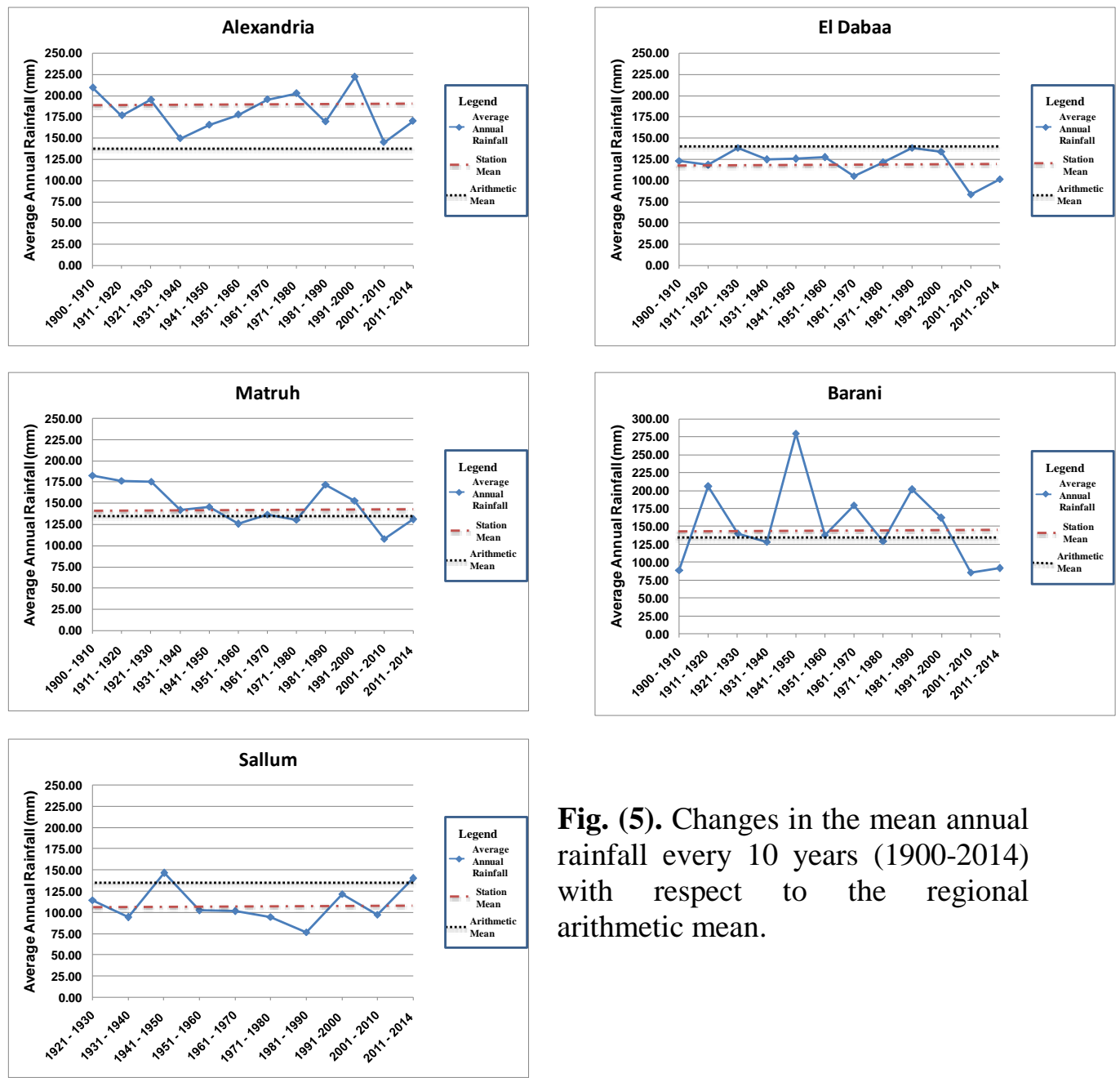

Fig. (5). Changes in the mean annual rainfall every 10 years (1900-2014) with respect to the regional arithmetic mean.

\subsection{Maximum rainfall in one day and number of rainy days}

The maximum rainfall in one day (Table 4) is considered as an indicator to determine the rainfall-runoff characteristics in the study area and the probability of runoff events that may recharge the shallow groundwater. From this table, the following are noticed; 
- The maximum rainfall in one day during the period (1900-2014) is recorded in Matruh location $(76.5 \mathrm{~mm})$ in October 1923, $(75.5 \mathrm{~mm})$ in October 1947 and $70.6 \mathrm{~mm}$ in January 1983. In Barrani, the maximum rainfall recorded in one day was $76 \mathrm{~mm}$ in October 1913.

- Most of the high values of maximum rainfall in one day were recorded in the autumn (September - November) and spring (March May) seasons, especially during the periods 1931-1940 and 19812000. This phenomenon means that the Northwestern coast was subjected to heavy storms during these particular periods, which may indicate a kind of periodical change in the rainfall behavior as a result of the global climatic change.

- The number of rainy days/year varies widely between the relative wet period (1910-1940) and the dry period (1995-2010), where it reaches 71 days in 1911 in Alexandria and 54 days in 1923 in Matruh. In the dry period, the rainy days/year in Alexandria is 14 days/year and 10 days/year in Matruh (2010).

- The number of runoff days (Storm $>10 \mathrm{~mm}$ ) are also recorded. It reaches about 5 days/year in the wet period, while in the dry period; it doesn't exceed 2days/year. The Zero value of runoff days/year means that no rainfall in this year caused runoff such as in the years 1959 and 2010 in Matruh and 1970 in Sallum, which indicates that the study area was subject to two drought periods (1955-1970) and (1995-2010).

Table (4). Maximum Rainfall in one day among the seasons (1900-2010).

\begin{tabular}{|c|c|c|c|c|c|c|c|c|c|c|c|c|}
\hline |lint & & Fotis & ta1- & Latis & nitite & Dיר & Lithe & Hotiv & orats: & 11-1. & L.17: & 2ny \\
\hline \multirow[b]{2}{*}{ 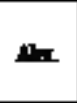 } & 5 & E. & I. & mir & W. & 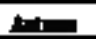 & Lt. & g」 & W. & Pـ & mir & t: \\
\hline & 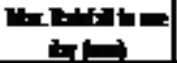 & si & $\pi$ & $\mathbf{z}$ & $\mathbf{2}$ & $\mathbf{x}$ & 71 & El & 51 & sta & $=$ & \\
\hline \multirow[b]{2}{*}{ הוn: } & 5. & wra & $m$ & Whar & Lئ & & m.r. & Wh & & t. & L & t. \\
\hline & 1. & $\mathbf{5 5}$ & $\mathbf{x}$ & 5 & $\mathbf{I}$ & - & $\mathbf{x}$ & an & - & $\mathbf{2 5 6}$ & it: & \\
\hline \multirow[b]{2}{*}{ 1!.h } & 5. & ma & ma & D. & . & t.t & L & Wh & $\boldsymbol{m}$ & ma & . & t. \\
\hline & 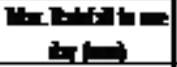 & 보 & $\mathbf{m}$ & KS & es & $\mathbf{B 5}$ & 55 & 41 & B: & nex & G7 & \\
\hline \multirow[b]{2}{*}{ Ir } & 5. & m. & 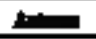 & 5ـ & 5. & & t. & mir & & t. & . & t: \\
\hline & 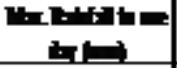 & 10 & $\boldsymbol{x}$ & $\mathbf{x}$ & & - & 31 & 317 & - & $\mathbf{5 u}$ & 39 & \\
\hline \multirow[b]{2}{*}{ ent } & 5 & & 5 & Er & s & I. & !r & Etr. & !r & ب. & Wh & In \\
\hline & 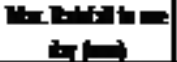 & & 2 & 9 & E7 & 포 & 춘 & 41 & 5: & 253 & stis & \\
\hline
\end{tabular}

\subsection{Rainfall frequency distribution}

The frequency of the annual rainfall (the count of the occurrences of values within a particular interval) and its percentage is calculated for the study area (Table 5 and Fig. 6), from which one can notice that Barrani, 
Matruh and Dabaa (middle locations) show nearly the same trend, while Sallum and Alexandria (extreme west and east) are quite different.

Sallum location received the lowest amount of rainfall (the maximum frequency $(57.8 \%$ ) recorded at annual rainfall less than $100 \mathrm{~mm}$ and decreases gradually), while Alexandria received the highest amount of rainfall (the maximum frequency $(37 \%)$ recognized for the annual rainfall between 150 and $200 \mathrm{~mm} /$ year).

Table (5). Frequency distribution of annual rainfall.

\begin{tabular}{|c|c|c|c|c|c|c|c|}
\hline Location & $\begin{array}{c}\text { AnnualRainfall } \\
(\mathrm{mm})\end{array}$ & $<100$ & $100-150$ & $150-200$ & $200-250$ & $250-300$ & $>300$ \\
\hline \hline \multirow{2}{*}{ Alexandria } & Frequency & 8 & 16 & 28 & 13 & 7 & 4 \\
\cline { 2 - 8 } & Percentage & $10.53 \%$ & $21.05 \%$ & $36.84 \%$ & $17.11 \%$ & $9.21 \%$ & $5.26 \%$ \\
\hline \hline \multirow{2}{*}{ El Dabaa } & Frequency & 22 & 30 & 14 & 7 & 3 & 0 \\
\cline { 2 - 8 } & Percentage & $28.95 \%$ & $39.47 \%$ & $18.42 \%$ & $9.21 \%$ & $3.95 \%$ & $0.00 \%$ \\
\hline \hline \multirow{2}{*}{ Matruh } & Frequency & 19 & 29 & 15 & 6 & 5 & 2 \\
\cline { 2 - 8 } & Percentage & $25.00 \%$ & $38.16 \%$ & $19.74 \%$ & $7.89 \%$ & $6.58 \%$ & $2.63 \%$ \\
\hline \hline \multirow{2}{*}{ Barrani } & Frequency & 15 & 29 & 19 & 10 & 0 & 3 \\
\cline { 2 - 8 } & Percentage & $19.74 \%$ & $38.16 \%$ & $25.00 \%$ & $13.16 \%$ & $0.00 \%$ & $3.95 \%$ \\
\hline \hline \multirow{2}{*}{ Sallum } & Frequency & 41 & 22 & 6 & 1 & 0 & 1 \\
\cline { 2 - 8 } & Percentage & $57.75 \%$ & $30.99 \%$ & $8.45 \%$ & $1.41 \%$ & $0.00 \%$ & $1.41 \%$ \\
\hline
\end{tabular}

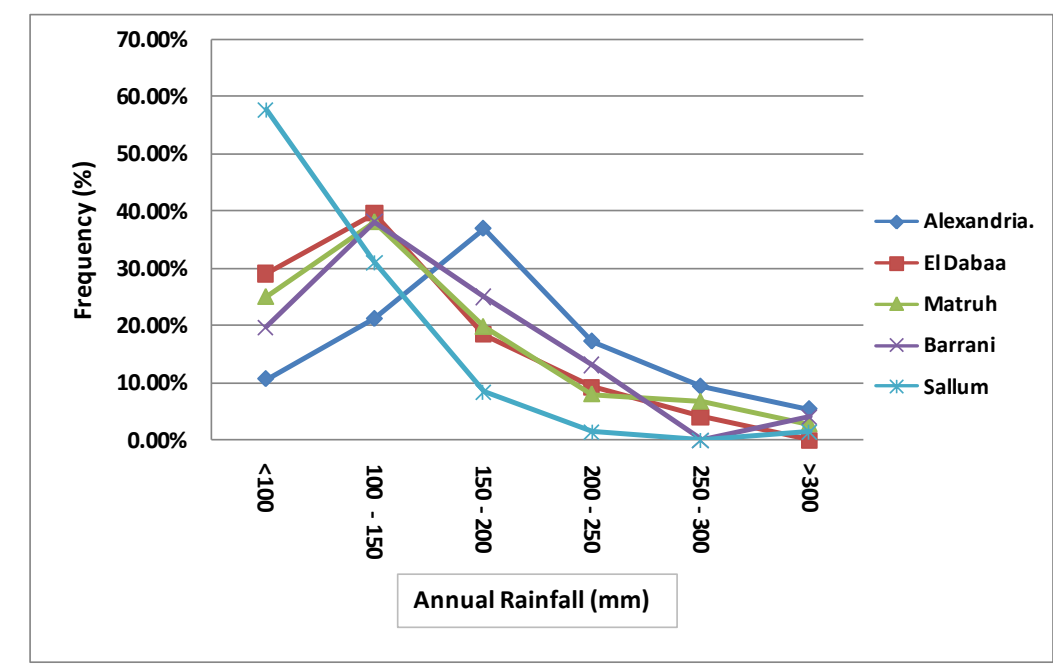

Fig. (6). Annual rainfall frequency percentage distribution.

\subsection{Return period and probability of exceedence}

A return period is an estimate of the interval of time between events like flood or a river discharge flow of a certain intensity or size. It is a statistical measure denoting the average recurrence interval over an extended period of time, and is usually used for risk analysis (e.g. to decide whether a 
project should be allowed to go forward in a zone of a certain risk, or to design structures to withstand an event with a certain return period) (Wiley, 2005).

The relation between the probability of exceedence $(\mathrm{G}(\mathrm{x}))$ and return period $(\mathrm{T})$ is given by the following formula (Ponce, 1989):

$$
\mathrm{G}(\mathrm{x})=1 / \mathrm{T}
$$

The most universally used formula for calculating the return period (T) for a particular peak discharge is that of Weibull (Brook, 1986):

Where;

$$
\mathrm{T}=(\mathrm{N}+1) / \mathrm{m} \text {. }
$$

$\mathrm{N}$ is the number of events in the series.

$\mathrm{m}$ is the rank (from largest to smallest) of each event in the series.

The above equations are applied to calculate the return period and probability of exceedence, for the maximum and minimum annual rainfall data, for the five locations in the study area. The results are tabulated in table (6). It is clear that increase the rainfall, the longer the return period and vice versa. For example, in Matruh, an annual rainfall of $384.5 \mathrm{~mm}$ can be expected to occur each 100 years with a probability of $1.15 \%$, while a rain of $34.3 \mathrm{~mm}$ can occur every year with a probability of $99.0 \%$.

To plot the relation between the return period and the average annual rainfall, the Log Pearson Type III Distribution is used (Rhind, 1909). This analysis depends on the following equations:-

$$
\text { Variance }=\frac{\sum_{i}^{n}(\log R-\operatorname{avg} .(\log R))^{2}}{n-1}
$$

$$
S V=\sqrt{\text { Variance }}
$$

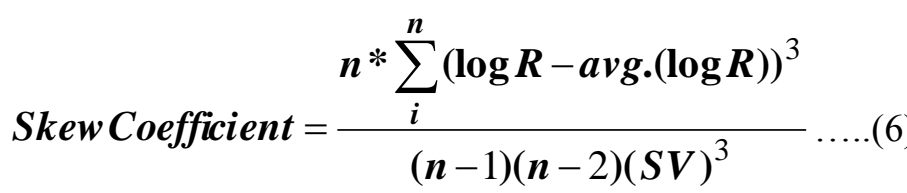

Where;

$$
\begin{aligned}
& \mathrm{R}=\text { Annual Rainfall }(\mathrm{mm}) \\
& \mathrm{n}=\text { Number of events in the series } \\
& \mathrm{SV}=\text { Standard Deviation }
\end{aligned}
$$

This relation was plotted for the five locations as shown in fig. (7). The equations resulted from this distribution, showing the relation between the average annual rainfall and the return period, is shown in table (7). From these relationships, it is quite obvious that the probability of occurrence of an amount of annual rainfall can be doubled (from the mean of the location) 
every sixty years in all stations except Sallum, where the probability of occurrence of an amount of annual rainfall can be doubled every only 30 years.

Table (6). Return Period and Probability for max. and min. annual rainfall.

\begin{tabular}{cccccccccc}
\hline \multirow{2}{*}{ Location } & Period & $\begin{array}{c}\text { Return } \\
\text { period } \\
\end{array}$ & & \multicolumn{3}{c}{ Max. annual rainfall } & \multicolumn{4}{c}{ Min. annual rainfall } \\
\cline { 5 - 10 } & & Year & $\begin{array}{c}\text { Value } \\
(\mathbf{m m})\end{array}$ & $\begin{array}{c}\text { Probability } \\
(\boldsymbol{\%})\end{array}$ & Year & $\begin{array}{c}\text { Value } \\
(\mathbf{m m})\end{array}$ & $\begin{array}{c}\text { Return } \\
\text { Period (year) }\end{array}$ & $\begin{array}{c}\text { Probability } \\
(\boldsymbol{\%})\end{array}$ \\
\hline Alexandria & $1900-2014$ & 114 & 1974 & 405.0 & 0.88 & 1931 & 33.2 & 1 & 99.10 \\
Dabaa & $1910-2014$ & 104 & 1989 & 288.9 & 1.10 & 1999 & 40.0 & 1 & 99.10 \\
Matruh & $1907-2014$ & 107 & 1930 & 384.8 & 1.15 & 1999 & 34.3 & 1 & 99.00 \\
Barrani & $1910-2014$ & 104 & 1911 & 375.7 & 1.10 & 2010 & 29.1 & 1 & 98.91 \\
Sallum & $1921-2014$ & 93 & 1953 & 324.0 & 1.14 & 1955 & 32.8 & 1 & 98.67 \\
\hline
\end{tabular}
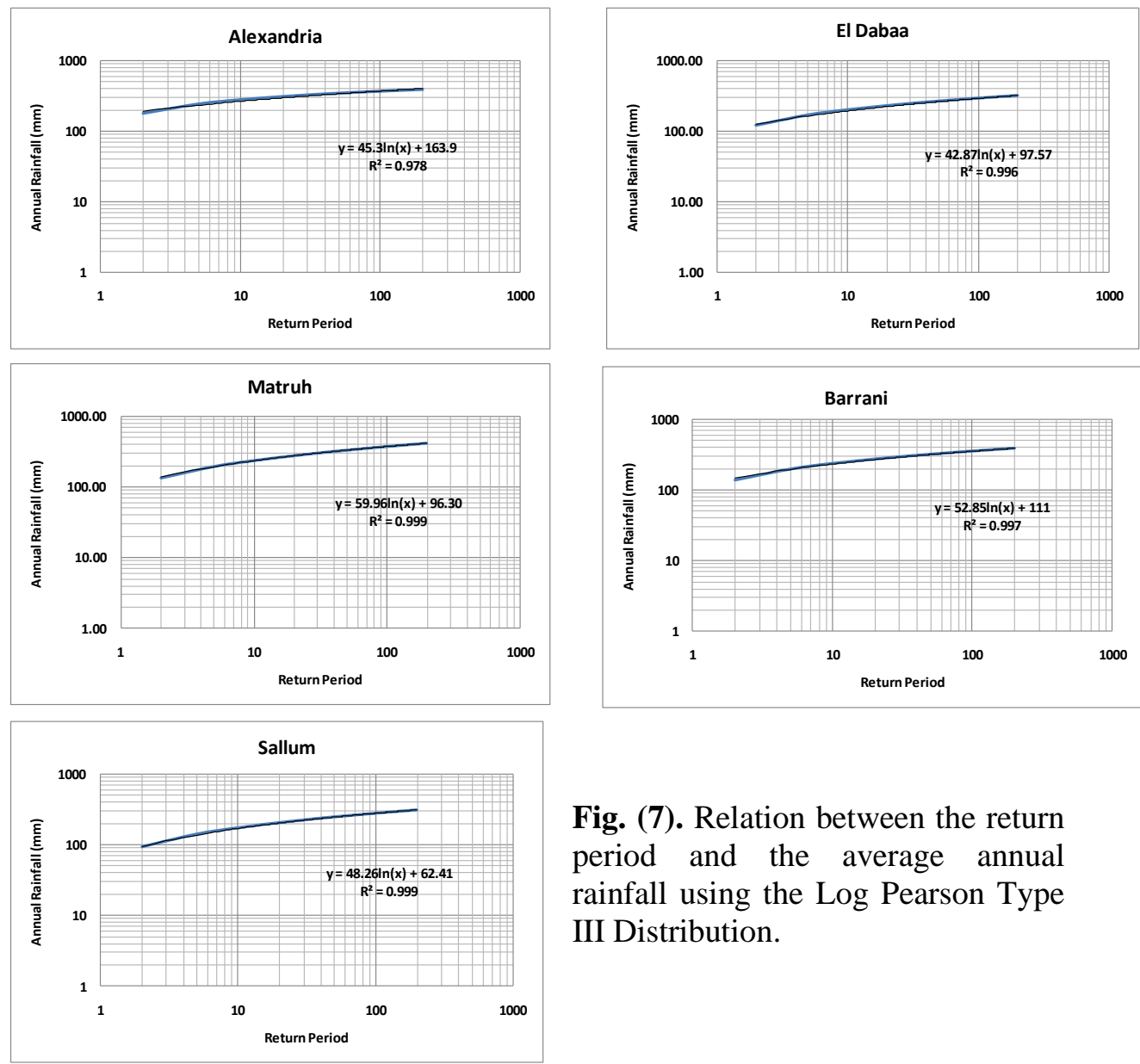

Fig. (7). Relation between the return period and the average annual rainfall using the Log Pearson Type III Distribution. 
Table (7). Results of Log Pearson Type III Distribution.

\begin{tabular}{|c|c|c|c|c|c|c|c|}
\hline \multirow[b]{2}{*}{ Location } & \multirow[b]{2}{*}{ Equation } & \multicolumn{6}{|c|}{ Annual rainfall (mm) } \\
\hline & & $\begin{array}{c}\text { Mean } \\
\text { annual } \\
\text { rainfall } \\
(\mathbf{m m})\end{array}$ & $\begin{array}{c}\text { Return } \\
\text { period } \\
10 \\
\text { years }\end{array}$ & $\begin{array}{c}\text { Return } \\
\text { period } \\
30 \\
\text { years }\end{array}$ & $\begin{array}{c}\text { Return } \\
\text { period } \\
60 \\
\text { years }\end{array}$ & $\begin{array}{c}\text { Return } \\
\text { period } \\
90 \\
\text { years }\end{array}$ & $\begin{array}{c}\text { Return } \\
\text { period } \\
120 \\
\text { years }\end{array}$ \\
\hline Alexandria & $y=45.3 \ln (x)+163.9$ & 184.2 & 268.09 & 317.97 & 349.37 & 367.74 & 380.77 \\
\hline Dabaa & $y=42.87 \ln (x)+97.57$ & 129.3 & 196.28 & 243.38 & 273.09 & 290.48 & 302.81 \\
\hline Matruh & $y=59.966 \ln (x)+96.30$ & 148.1 & 234.38 & 300.26 & 341.82 & 366.14 & 383.39 \\
\hline Barrani & $y=52.85 \ln (x)+111$ & 151.6 & 232.69 & 290.75 & 327.39 & 348.81 & 364.02 \\
\hline Sallum & $y=48.26 \ln (x)+62.41$ & 104.2 & 173.53 & 226.55 & 260.00 & 279.57 & 380.77 \\
\hline
\end{tabular}

\section{Temperature Analysis}

One of the important indicators for climate change is the change in temperature. The data collected for the maximum and minimum temperature over 114 years (EMA, 1900-1994 and Global Weather, 1995-2014), are analyzed and plotted according to the seasons (Fig. 8). The results show that there is a noticeable increase in temperature in all stations but at different periods as follows:

- A considerable increase is noticed in 1955 - 1960, 1990 - 1995 and 2010 in Sallum, Matruh and Alexandria locations.

- A noticeable increase in the years 1995 - 2010 is in Barrani and Dabaa locations.

However, a noticeable increase in the temperature in the periods 1955-1970 and 1995-2010, means that these periods are the warmest period during the last century. These results are also matching with the global results, according to Hansen et al. (2000) where the global surface temperature in 1998 was the warmest in the last century. Worth mentioning, it can be noticed that the year 2010 is one of the warmest year during this century. As mentioned before this year had the lowest amount of rainfall in all the study area, which emphasizes the inverse relationship between the rainfall and temperature in the arid and semi arid region.

\section{Aridity Index}

The aridity index (AI) is a numerical indicator of the degree of dryness of the climate at a given location. It is usually expressed as a function of rainfall and potential evapotranspiration. In the study area, the aridity index is calculated based on the equation developed by UNEP (1992) as follows:- 
Where;

Aridity Index $=($ P/ PET $)$

$\mathrm{P} \quad$ is the average annual precipitation $(\mathrm{mm})$

PET is the potential annual evapotranspiration $(\mathrm{mm})$
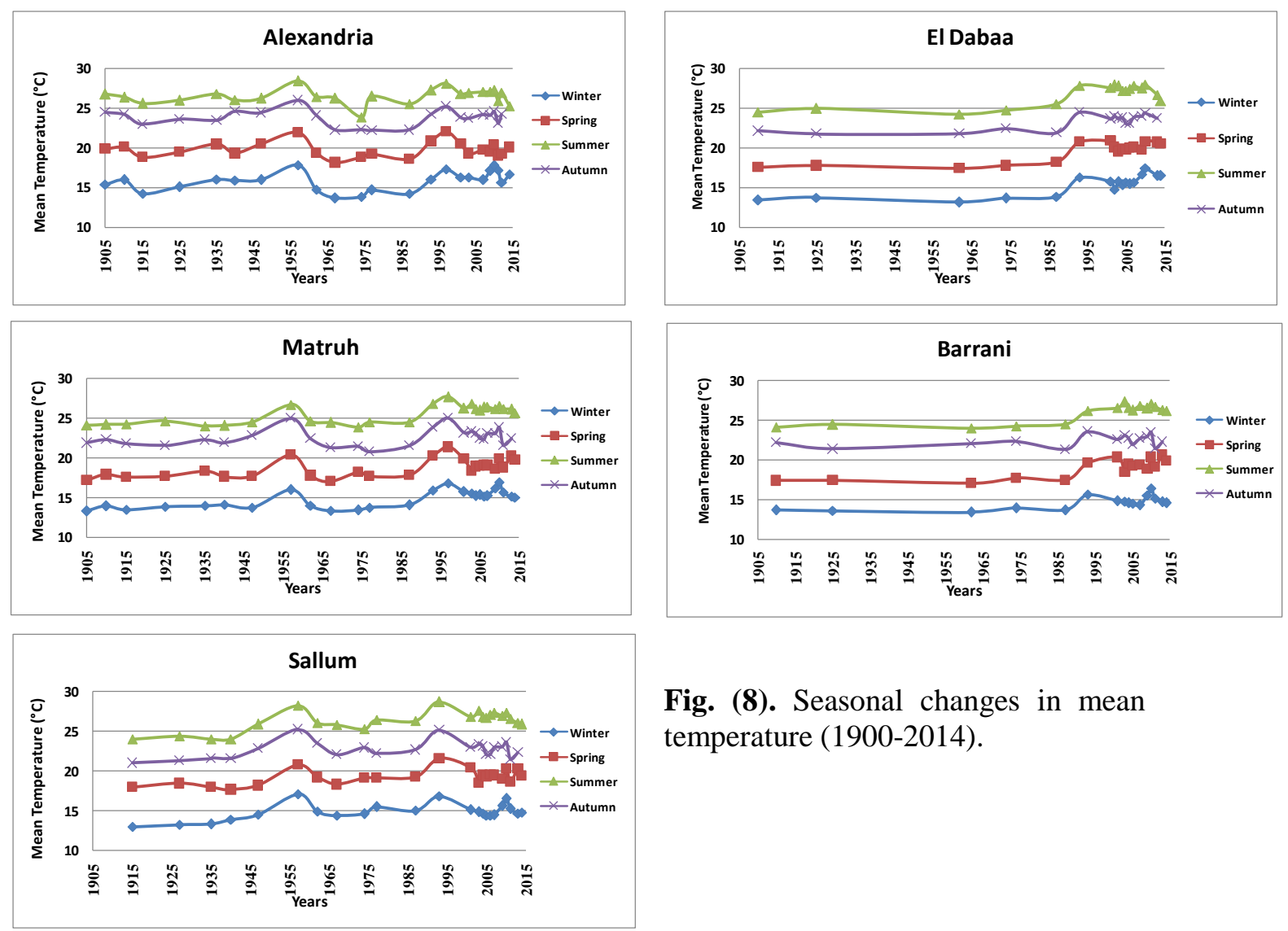

Fig. (8). Seasonal changes in mean temperature (1900-2014).

The potential evapotranspiration has been calculated using Thornthwaite equation (Thornthwaite, 1948). The climate is classified according to UNEP classification (Table 8). The calculated values (Table 9) indicate that Dabaa, Matruh and Sallum, exhibit hyper -arid condition, while Alexandria exhibits arid condition. Actually, there is no significant variation of the aridity classification for each individual location by time during the last century (1900-2000), while in the present century, all the study area, except Alexandria region, are classified as a hyper arid region. This result is matching with the results of annual rainfall and temperature as mentioned before. However, such condition indicates water deficits in the whole sector 
west of Dabaa, while water surplus is encountered only in Alexandria. Worth mentioning, the area between Alexandria and Alamein is now supplied by surface water through an open canal (El Hammam canal) for irrigation purpose.

Table (8). Climatic classification according to UNEP (1992).

\begin{tabular}{ccccc} 
Classification & Hyper-arid & Arid & Semi-arid & Sub-humid \\
\hline Aridity Index & $\mathrm{AI}<0.05$ & $\begin{array}{c}0.05<\mathrm{AI} \\
<0.20\end{array}$ & $\begin{array}{c}0.20<\mathrm{AI} \\
<0.50\end{array}$ & $\begin{array}{c}0.50<\mathrm{AI} \\
0.65\end{array}$
\end{tabular}

Table (9). Temporal variation of aridity index using UNEP equation.

\begin{tabular}{|c|c|c|c|c|c|}
\hline Station & Year & $\begin{array}{c}\text { Average Annual } \\
\text { Rainfall (mm) }\end{array}$ & $\begin{array}{c}\text { Potential } \\
\text { Evapotranspiration } \\
(\mathbf{m m})\end{array}$ & Aridity Index & Classification \\
\hline \multirow{5}{*}{ Alexandria } & $1900-1925$ & 199.9 & 3441.9 & 0.058 & Arid \\
\hline & $1926-1950$ & 166.8 & 3389.39 & 0.049 & Arid \\
\hline & $1951-1975$ & 195.6 & 3099.18 & 0.063 & Arid \\
\hline & $1976-2000$ & 226.3 & 3091.77 & 0.073 & Arid \\
\hline & $2001-2014$ & 150.8 & 2632.86 & 0.057 & Arid \\
\hline \multirow{5}{*}{ Dabaa } & $1900-1925$ & 121.7 & 2894.8 & 0.042 & Hyper Arid \\
\hline & $1926-1950$ & 132.8 & 2930.31 & 0.045 & Hyper Arid \\
\hline & $1951-1975$ & 124.2 & 2942.154 & 0.042 & Hyper Arid \\
\hline & 1976 - 2000 & 137.3 & 2689.553 & 0.051 & Arid \\
\hline & $2001-2014$ & 87.5 & 2653.76 & 0.033 & Hyper Arid \\
\hline \multirow{5}{*}{ Matruh } & $1900-1925$ & 169.7 & 2820.16 & 0.060 & Arid \\
\hline & 1926 - 1950 & 156.5 & 2804.87 & 0.056 & Arid \\
\hline & $1951-1975$ & 130.8 & 2841.85 & 0.046 & Hyper Arid \\
\hline & $1976-2000$ & 147.3 & 2886.78 & 0.051 & Arid \\
\hline & $2001-2014$ & 113.2 & 2553.24 & 0.044 & Hyper Arid \\
\hline \multirow{5}{*}{ Barrani } & $1900-1925$ & 173.4 & 2843.54 & 0.061 & Arid \\
\hline & 1926 - 1950 & 146.7 & 2834.19 & 0.052 & Arid \\
\hline & $1951-1975$ & 155 & 2805.31 & 0.055 & Arid \\
\hline & $1976-2000$ & 191.5 & 2670.78 & 0.072 & Arid \\
\hline & $2001-2014$ & 84.2 & 2574.06 & 0.033 & Hyper Arid \\
\hline \multirow{5}{*}{ Sallum } & $1900-1925$ & 104.9 & 3137.43 & 0.033 & Hyper Arid \\
\hline & $1926-1950$ & 115.2 & 2890.44 & 0.040 & Hyper Arid \\
\hline & 1951 - 1975 & 95.4 & 3108.65 & 0.031 & Hyper Arid \\
\hline & $1976-2000$ & 103.7 & 3217.43 & 0.032 & Hyper Arid \\
\hline & $2001-2014$ & 107.04 & 2561.2 & 0.042 & Hyper Arid \\
\hline
\end{tabular}

\section{Impact of Climate Change on Groundwater Potentials}

In order to assess the impact of climate change in the study area, the changes in groundwater levels and salinities at different localities during the period 1970- 2010 have been monitored and summarized in table (1•). The 
investigated water points (100 wells) (Fig. 9) were monitored, sampled and chemically analyzed in the present work (2010), keeping in mind that the whole terrain is composed of limestone rocks, where the runoff exceeds the infiltration rate in most of the area except those wells very close to the shoreline, where the Quaternary deposits are more permeable.

From table (10), it can be noticed that the salinity, in the present work, in the whole area ranges between less than 5000 and 15000 ppm, while the area lies directly to the east of Barrani exhibits the lowest category of groundwater salinity (1000-5000) ppm among the whole investigated area . Bearing in mind that the coastal plain in this particular area is dissected by more than 89 wadis of different lengths and widths. Naturally, the ability of direct recharge of the Quaternary aquifer by local rainfall is expected to be much favorable through the wadi fill deposits and along the shoreline. Besides, this particular area is characterized by relatively heavy rainfall of irregular peaks indicating cyclic climate regime during the last century in general and the drought periods in particular (1995-2010).

The area of Dabaa is less influencing by climatic change and therefore no significant changes in groundwater salinity have been noticed. The area of Matruh-Sallum is more affected by the climatic variation expressed in rainfall storms amount and drought events. However, this may be attributed to physiographic features resulted in favorable climatic conditions, where the Marmarica Plateau is plunged perpendicular to the wind direction.

Previous data (Atwa, 1979 and Saleh, 2000) of groundwater salinity in this area gave lower salinity values in general than the present status. The present deterioration of groundwater quality is mainly attributed to the overpumping by the inhabitants to compensate water shortage in the dry periods dominated during the last two decades in the study area.

Both processes (over exploitation and climatic change) cause serious reduction of the thickness of the fresh water lens that floats by specific gravity on the top of the saline water dominating the Mediterranean coast of Egypt (Adbel-Mogheeth and El Shazly, 1978). Moreover, in the coastal aquifers, the decrease of the fresh water thickness due to any hydrologic or climatic reason is gradually replaced by saline water according to GhybenHerzberg principle (De Wiest, 1965).

Egyptian J. Desert Res., 65, No. 2, 233-255 (2015) 
Table ( •). Groundwater level and salinity changes from 1970 to 2010.

\begin{tabular}{|c|c|c|c|c|c|c|}
\hline \multirow[b]{2}{*}{ Location } & \multicolumn{2}{|c|}{1970 (ATWA, 1979) } & \multicolumn{2}{|c|}{1998 (Saleh, 2000) } & \multicolumn{2}{|c|}{ (Present work) 2010} \\
\hline & $\begin{array}{l}\text { Ground- } \\
\text { water level } \\
\text { range }(\mathbf{m}) \\
\text { (a.m.s.l.) }\end{array}$ & $\begin{array}{c}\text { Ground- } \\
\text { water salinity } \\
(\mathbf{p p m})\end{array}$ & $\begin{array}{l}\text { Ground- } \\
\text { water level } \\
\text { range (m) } \\
\text { (a.m.s.l.) }\end{array}$ & $\begin{array}{l}\text { Ground- } \\
\text { water } \\
\text { salinity } \\
(\mathbf{p p m}) \\
\end{array}$ & $\begin{array}{c}\text { Ground- } \\
\text { water level } \\
\text { range (m) } \\
\text { (a.m.s.l.) }\end{array}$ & $\begin{array}{c}\text { Ground- } \\
\text { water } \\
\text { salinity } \\
\text { (ppm) }\end{array}$ \\
\hline Dabaa & +0.25 to +2.0 & $2000-6000$ & +7.0 to +11.50 & $1300-8300$ & $\begin{array}{l}-4.0 \text { to } \\
+13.0\end{array}$ & $3000-6000$ \\
\hline $\begin{array}{l}\text { Fuka (west } \\
\text { Dabaa) }\end{array}$ & +0.5 & $1000-3000$ & +8.75 & 2700 & $\begin{array}{c}-16.0 \text { to } \\
+1.0\end{array}$ & $7000-15000$ \\
\hline Ras El Hekma & +1.0 to +6.0 & $1000-5000$ & +8.0 & 470 & -6.0 to +2.0 & $5000-14000$ \\
\hline Matruh & +0.5 to +0.9 & $1000-6000$ & +5.0 to +19.0 & $470-6500$ & $\begin{array}{l}-7.0 \text { to } \\
+11.0\end{array}$ & $2500-15000$ \\
\hline West Matruh & +6.0 to +13.0 & $2000-6000$ & & & -2.0 to +3.0 & $5000-13000$ \\
\hline East Barrani & +9.0 to +12.0 & $1000-3000$ & & & $\begin{array}{l}+1.0 \text { to } \\
+8.0\end{array}$ & $1000-5000$ \\
\hline Barrani- Sallum & & $2500-6000$ & -1.5 to +8.80 & $2000-5200$ & -7.0 to +3.0 & $2000-16000$ \\
\hline
\end{tabular}

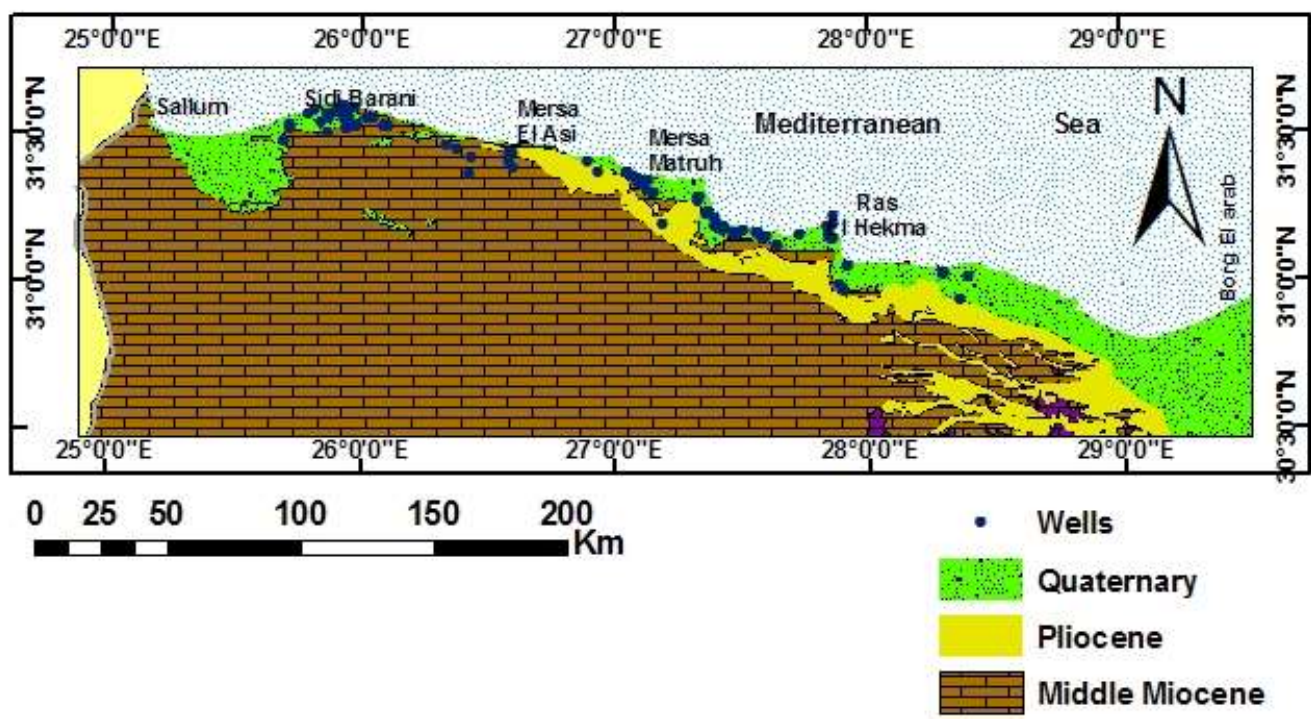

Fig. (9). Location of wells in the study area.

\section{CONCLUSION}

The analysis of the climatic data through the period (1900-2014) indicates that the amount of annual rainfall shows a noticeable increase from west $(104.6 \mathrm{~mm})$ to east $(180.8 \mathrm{~mm})$, with an arithmetic mean equals 138.44 
$\mathrm{mm}$. Three modes of rainfall characteristics are detected in the study area, i.e. oscillation far below or above the arithmetic mean as in Sallum and Alexandria respectively and oscillation very close to the arithmetic mean (Matruh and Dabaa). Cycles of peaks and troughs every 30 years are very clear in Barrani area, causing serious runoff through a number of prolongate catchment areas. Local climatic changes every 15 years or multiples in the study area are detected through the period 1900-2014. Although the study area is characterized by winter rainfall (Mediterranean climate), heavy storms occur frequently in the autumn and spring season everywhere.

Two dry periods (1955-1970 and 1995-2010) and one relative wet period (1910-1940) are strongly detected in the study area during the years 1900-2014. The return period and probability of exceedence show that the higher the amount of rainfall the longer the return period and vice versa. The probability of occurrence of an amount of annual rainfall can be doubled (from the mean of the location) every sixty years in all stations except Sallum, where the probability of occurrence of an amount of annual rainfall can be doubled every only 30 years.

However, Barran-Matruh sector $(140 \mathrm{~km})$ is nearly similar from the physiographic and climatologic points of view, since the rainfall water divide lies at the same distance from the shore line i.e. $30.0 \mathrm{~km}$, leading to hazardous runoff at heavy storm events. A number of 89 wadis are running towards the shoreline in this particular sector, dissecting the Miocene plateau to the coasts. For such wadis, runoff harvesting techniques are also recommended.

The scanty rainfall and successive drought periods in the study area, lead to an intensive well drilling, to use groundwater as a supplement source for irrigation, where the number of drilled wells during the last two decades increased by $500 \%$. The impact of such condition upon groundwater potentials shows accelerated lowering of water levels associated with increase of water salinity in all localities within the study area but at different rates. In general, the groundwater data of 1970 and the present status show water levels decrease by maximum $16.0 \mathrm{~m}$ reaching the zero level or even below in most localities. On the other side, water salinity increased from average $3000 \mathrm{ppm}$ in 1970 to more than $10000 \mathrm{ppm}$ in 2010. Although, the frequent drought condition prevailed in most of the study area during the last third of the past century is responsible for such groundwater deterioration, one should also focus on the over-pumping as one of the main threats.

Egyptian J. Desert Res., 65, No. 2, 233-255 (2015) 


\section{REFERENCES}

Abdel-Mogheeth, S.M. and El Shazly, M.M. (1978). Characteristics of the fresh water lens floating on the top of the main water table in SidiKirir area. Desert Research Center Bulletin, Egypt.

Atwa, S.M. (1979). Hydrogeology and hydrochemistry of the North West Coastal Zone, Egypt. Ph.D. Thesis, Faculty of Science, Ain Shams University, Cairo, Egypt.

Brook, R.J. (1986). In "The Fascination of Statistics ". CRC Press, New York.

CONOCO Inc. (1989). Stratigraphic lexicon and explanatory notes to the geological map of Egypt, 1- 500,000. CONOCO Inc., Cairo, Egypt.

De Wiest, R.J.M. (1965). In "Geohydrology". John Wiley and Sons, New York, 366 pp.

EMA (1900-1994). Egyptian Meteorological Authority. Available online: http://www.lib.noaa.gov/collections/foreign_climate_data_pages/for eign_climate_data_egypt.html.

FAO (1970). Pre-investment survey on the Northwestern Coastal Zone, physical conditions and water resources. United Nations Development Programme.

Global Weather (2014). Available online: http://globalweather.tamu.edu/.

Hansen, J., M. Sato, J. Glascoe and R. Ruedy (2000). GISS analysis of surface temperature change. NASA Goddard Institute for Space Studies, New York.

NASA (1995-2014). Available online: http://disc2.nascom.nasa.gov/Giovanni/tovas/.

NOAA National Weather Service (2007). Available online: http://www.nws.noaa.gov/os/brochures/climate/Climatechange.

Physical Map of Egypt (2014). Available online: http://www. freeworldmaps.net /africa /egypt/ map.html.

Ponce, V.M. (1989). In "Engineering Hydrology, Principle and practices". Prentice-Hall, New Jersey.

Reed, J.F., F. Lynn and B.D. Meade (2002). Use of coefficient of variation in assessing variability of quantitative assays. Clin. Diagn. Lab. Immunol., 9 (6): 1235-1239.

Rhind, A. (1909). Tables to facilitate the computation of the probable errors of the chief constants of skew frequency distributions. Biometrika, 7 (1/2): 127-147. JSTOR 2345367.

Saleh, A. (2000). Hydrological, geomorphological and geonvironmental implications for future sustainable development of the Northwestern Coastal Zone of Egypt. Ph.D. Thesis, Faculty of Science. Mansoura University, Mansoura, Egypt.

Thornthwaite, C.W. (1948). An approach toward a rational classification of climatic. Geographic Review, 38 (1): 55-94. 
UNEP (1992). World Atlas of Desertification. the United Nations Environment Programme (UNEP), London.

Wiley, J. (2005). In "Water Resources Engineering, 2005 Edition". John Wiley and Sons Inc.

Zaki, M.H. (2000). Assessment of surface water runoff in mersa matruh area, Northwestern Coastal Zone, A.R.E. Ph.D. Thesis, Faculty of Science, Alexandria University, Alexandria, Egypt. 

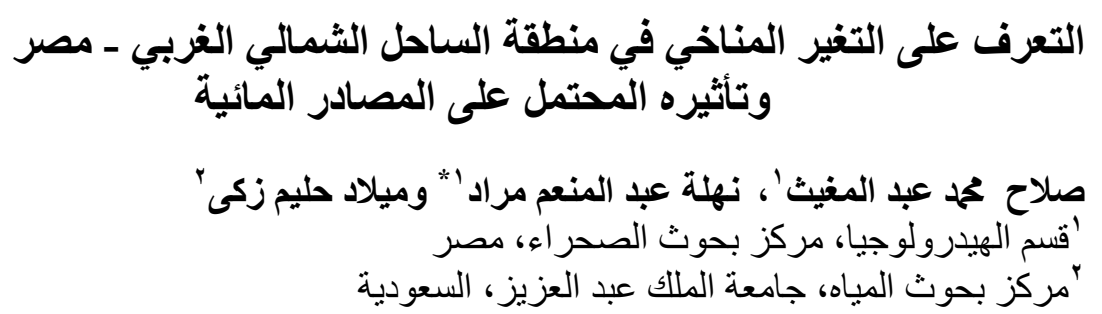

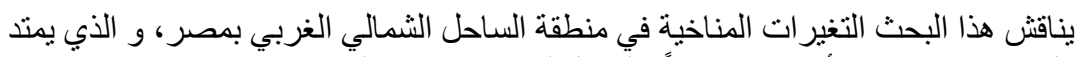

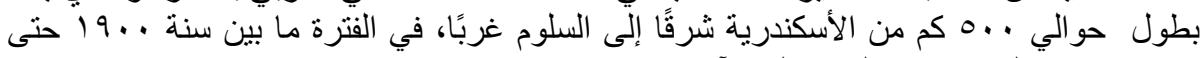

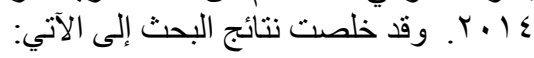

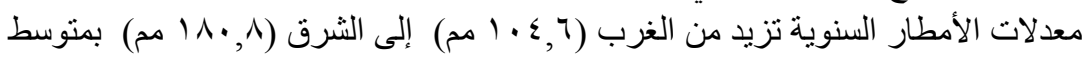

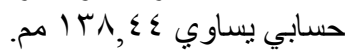

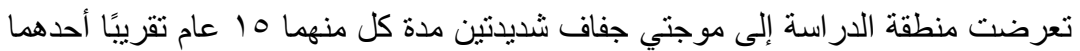

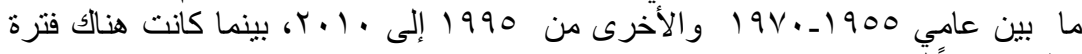

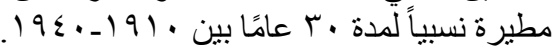

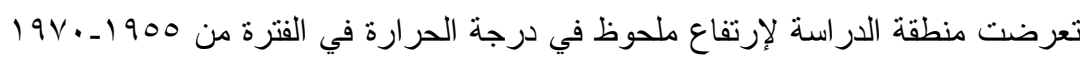
$r \cdot 1 \cdot-1990$,

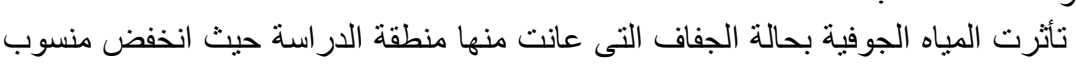

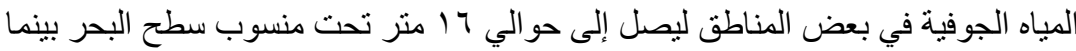

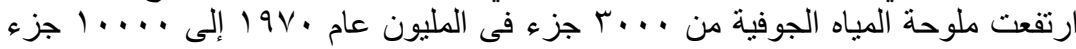

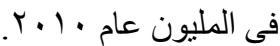

يرجع هذا الإنخفاض في منسوب المياه الجوفية والمصحوب بزيادة في الملوحة إلى عاملين

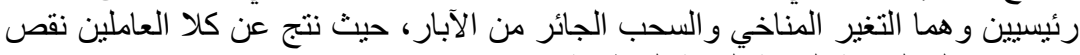
حاد في سمك العدسة المائية ألعذبة السطحية.

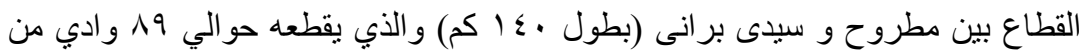

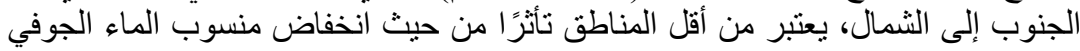

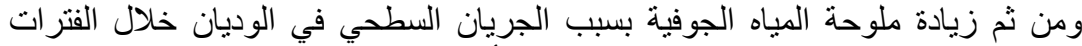
المطيرة، وبالتالي يجدر الإهتمام بحصاد مياه الأمطار و السيول في هذا الجزء لئ من منطقة الجيان 